\title{
POLY(LACTIC-CO-GLYCOLIC ACID) BASED DRUG DELIVERY DEVICES FOR TISSUE ENGINEERING AND REGENERATIVE MEDICINE
}

\author{
Oya KERIMOĞLU, Emine ALARÇİN
}

Marmara Üniversitesi Eczacılık Fakültesi, Farmasötik Teknoloji Anabilim Dalı, Haydarpaşa, İSTANBUL

\section{SUMMARY}

Poly(D,L-lactide-co-glycolide) (PLGA) is the most frequently used biodegradable polymer for developing nano/ microparticles encapsulating therapeutic drugs in controlled release (CR) applications. PLGA based drug delivery devices have several advantages over the conventional devices. One of the advantage is the extended release rates of drugs up to days, weeks or months. Other reasons for the widespread use of PLGA are its biodegradability, its biocompatibility, and the fact that PLGA has been approved by FDA (Food and Drug Administration). Numerous active pharmaceutical ingredients such as anticancer drugs, analgesics, antibiotics and macromolecular drugs such as proteins, peptides, genes, vaccines, antigens, human growth factors, vascular endothelial growth factors etc., are successfully incorporated into PLGA or PLGA based drug delivery devices. As a result, these systems in general can be used to provide targeted (cellular or tissue) delivery of drugs, which localized effect represents also an important benefit. They improve bioavailability, sustain release of drugs or solubilize drugs for systemic delivery. Drug delivery using PLGA or PLGA based polymers is an attractive area with various opportunities for further research and developmental work.

In this review, physicochemical and biodegradable properties of PLGA and PLGA based drug delivery devices for tissue engineering and regenerative medicine will be presented.

Keywords: controlled release, PLGA, polymer, regenerative medicine, tissue engineering

\section{ÖZET}

\section{Doku Mühendisliği ve Rejeneratif Tıpta Kullanılan Poli (laktik-ko-glikolik asit) ile Hazırlanmış İlaç Sistemleri}

Poli(D,L-laktid-ko-glikolid) (PLGA) kontrollü salım (KS) uygulamalarında terapötik ilaçları enkapsüle eden nano/ mikropartiküllerin geliştirilmesinde sıklıkla kullanılan biyolojik olarak parçalanma özelliğine sahip bir polimerdir. PLGA ile hazırlanmış ilaç sistemlerinin konvansiyonel sistemlere göre çok sayıda avantajı bulunmaktadır. Bu avantajlardan biri, ilaçların uzatılmıs salım özelliklerinin günler, haftalar veya aylarca devam edebilmesidir. PLGA'nın yaygın kullanımının diğger sebepleri ise biyolojik olarak parçalanabilir olması, biyolojik olarak geçimli olması ve FDA (Gıda ve İlaç İdaresi) tarafindan onaylanmış olmasıdır. Kanser tedavisinde kullanılan ilaçlar, analjezikler, antibiyotikler gibi çeşitli aktif farmasötik ajanların yanısıra protein, peptid, gen, aşı, antijen, insan büyüme faktörleri, vasküler endotelial büyüme faktörleri gibi makromoleküler yapıdaki çeşitli ilaçlar PLGA veya PLGA ile hazırlanmış ilaç sistemleri içerisine başarılı bir şekilde yüklenebilmektedir. Sonuç olarak bu sistemler genel olarak ilaçlarm hedeflendirilmesinde (hücresel veya doku temelinde), ayrica lokal etkilerinin de fayda sağlayacă̆ı sistemlerde kullanılmaktadır. Biyoyararlanımı artırırlar, ilaç salımını uzatırlar veya sistemik etki amacıyla ilaçların çözünmesini sağlarlar. Gelecekte yapılacak araştırma ve geliştirme çalışmalarında PLGA veya PLGA ile hazırlanmış ilaç sistemleri çeşitli avantajlarından dolayı ilgi çekici bir alandır.

Bu derlemede PLGA'nın fizikokimyasal ve biyolojik olarak parçalanma özelliklerinin yanısıra doku mühendisliği ve rejeneratif tıp için PLGA ile hazırlanmış ilaç sistemleri sunulmaktadır.

Anahtar sözcükler: doku mühendisliği, kontrollü salım, PLGA, polimer, rejeneratif tıp

Corresponding author: Emine Alarçin. Marmara Üniversiteși Eczacılık Fakültesi, Farmasötik Teknoloji Anabilim Dalı, Haydarpaşa, İTTANBUL

Tel: (0216) 41429 62/1234; GSM: (0505) 4127809

e-mail: eminealarcin@gmail.com

Recieved: 24 April 2012, accepted: 05 June 2012 


\section{INTRODUCTION}

Polymers are the primary materials for drug delivery devices and scaffold fabrication in tissue engineering applications. and many types of biodegradable polymeric materials have been already used in this field. A wide variety of natural and synthetic biodegradable polymers have been investigated in this field. Naturally derived polymers have the potential advantage of biological recognition that may positively support cell adhesion and function, but the use of these natural polymers is limited due to their higher costs and questionable purity and poor mechanical properties. Synthetic biodegradable polymers have been increasingly used to deliver drugs, since they are free from most of the problems associated with the natural polymers. They have relatively good mechanical strength and their shape and degradation rate can be easily modified, but their surfaces are hydrophobic and lack of cell-recognition signals. Poly(amides), poly (amino acids), poly (alkyl-a-cyano acrylates), poly(esters), poly (orthoesters), poly (urethanes), and poly(acrylamides) have been used to prepare various drug loaded devices. Among them, the thermoplastic aliphatic poly(esters) like PLA, PGA, and especially PLGA have generated tremendous interest due to their excellent biocompatibility and biodegradability ${ }^{(3,38,61)}$.

Poly(D,L-lactide-co-glycolide) (PLGA) and its various derivatives have been the center focus for developing nano/microparticles encapsulating therapeutic drugs in controlled release (CR) applications due to their advantages over the conventional devices that include extended release rates up to days, weeks or months, in addition to their biocompatibility/ biodegradability and ease of administration via injection $^{(11,38,44,54)}$. Macromolecular drugs such as proteins, peptides, genes, vaccines, antigens, human growth factors, vascular endothelial growth factors etc., are successfully incorporated into PLGA or PLGA based nano/microparticles. Also, PLGA has been approved by the Food and Drug Administration (FDA) for drug delivery device ${ }^{(1,6,17,38,42,63,71,72)}$. The list of FDA approved CR products of PLGA is given in Table $1^{(54)}$.

In this review, physicochemical and biodegradable properties of PLGA and PLGA based drug delivery devices for tissue engineering and regenerative medicine will be presented.

\section{PHYSICOCHEMICAL PROPERTIES OF PLGA}

Poly(lactic acid) (PLA) is a linear aliphatic thermoplastic polyester, produced by polymerization of lactide, a cyclic dimer derived from lactic acid. It is a chiral molecule and can be produced as poly (L-lactide), poly (D-lactide), and the racemic poly (D,L-lactide). PLA is soluble in common organic solvents. Poly(glycolic acid) (PGA) is the simplest linear, aliphatic polyester. Since PGA is highly crystalline, it has a high melting point and low solubility in organic solvents. PGA's high crystallinity is because of its chemical structure lacking the methyl side groups of the PLA ${ }^{(56,61,66)}$. PLGA is a copolymer of lactide and glycolide, which is synthesized by means of random ring-opening and when PGA randomly copolymerized (30-50 \%) with PLA, resulting copolymer (PLGA) retains physical properties more readily amenable to processing

Table 1. PLGA-based microparticles available in the market ${ }^{(54)}$.

\begin{tabular}{|c|c|c|c|}
\hline Product name & Active ingredient & Company & Application \\
\hline Lupron Depot ${ }^{\circledR}$ & Leuprolide acetate & TAP & Prostate cancer \\
\hline Nutropin Depot ${ }^{\circledR}$ & Growth hormone & Genetech & $\begin{array}{l}\text { Pediatric growth hormone } \\
\text { deficiency }\end{array}$ \\
\hline Suprecur ${ }^{\circledR} \mathrm{MP}$ & Buserelin acetate & Aventis & Prostate cancer \\
\hline Decapeptyl ${ }^{\circledR}$ & Triptorelin pamoate & Ferring & Prostate cancer \\
\hline Sandostatin LAR ${ }^{\circledR}$ Depot & Octreotide acetate & Novartis & Acromegaly \\
\hline Somatuline ${ }^{\circledR}$ LA & Lanreotide & Ipsen & Acromegaly \\
\hline Trelstar ${ }^{\mathrm{TM}}$ Depot & Triptorelin pamoate & Pfizer & Prostate cancer \\
\hline Arestin $^{\circledR}$ & Minocycline & Orapharma & Periodontal disease \\
\hline Risperidal $^{\circledR}$ Consta $^{\mathrm{TM}}$ & Risperidone & Johnson \& Johnson & Antipsychotic \\
\hline
\end{tabular}


(those of low-melting thermoplastic with good solubility in common solvents). The degradation rate of PLGA is much faster than that of PLA due to the component glycolic acid in the backbone, and in addition the degradation rate can be adjusted by varying the amounts of glycolic acid and lactic acid ${ }^{(7,18,38,39,66,81,87)}$.

The $\mathrm{Tg}$ (glass transition temperature) of the PLGA copolymers are above the physiological temperature of $37^{\circ} \mathrm{C}$ and hence they are glassy in nature. They have a fairly rigid chain structure which gives them significant mechanical strength to be formulated as drug delivery devices $^{(3,50,81)}$. Tg of PLGAs decrease with decrease of their lactide content in the copolymer composition and with decrease in their molecular weight ${ }^{(3,40)}$.

PLGA polymers are subjected to physical stress when using as drug delivery devices so they should have a considerable mechanical strength $^{(50,81)}$. Different factors like the molecular weight, copolymer composition (lactide/glycolide ratio), crystallinity and geometric regularity of individual chains significantly affect the mechanical strength of the polymer ${ }^{(39,50,81)}$.

\section{BIOLOGICAL PROPERTIES AND BIODEGRADATION OF PLGA}

The design and development of biodegradable drug delivery devices for therapeutical application require a well understanding of the in vivo biodegradation phenomena and also the cellular and tissue responses which determine the biocompatibility of the biodegradable drug delivery devices ${ }^{(69)}$.

PLGA is one of the most successfully used biodegradable polymer because it undergoes hydrolysis in the body to produce the biodegradable and biocompatible metabolite monomers (lactic acid and glycolic acid) that are eventually removed from the body by the citric acid cycle (Fig. 1). Polymer biodegradation products are formed at a very slow rate and hence they do not affect the normal cell function. Since the body effectively deals with these two monomers, there is very minimal or no systemic toxicity associated by using PLGA for drug delivery or biomaterial applications ${ }^{(7,34,46,58)}$. The drug entrapped in the PLGA matrix system is released at a sustained rate through diffusion of the drug and by degradation of the polymer matrix (Fig. 2) $)^{(7,58,69) \text {. }}$

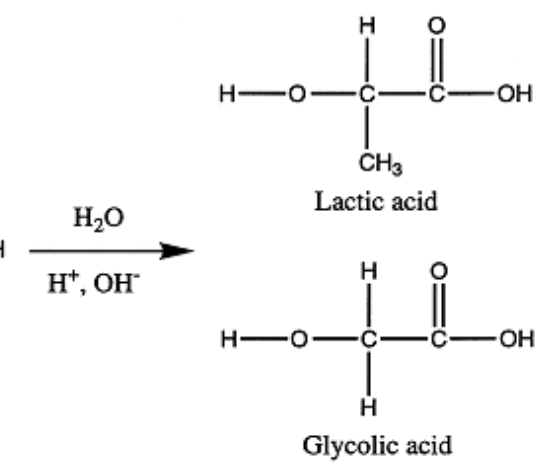<smiles>CC(C)OCC(=O)C(C)OC(=O)C(C)(C)C(=O)C(C)O</smiles>

Poly(lactic-co-glycolic acid)

Figure 1. PLGA undergoes hydrolysis in the body to produce lactic acid and glycolic acid ${ }^{(7)}$.
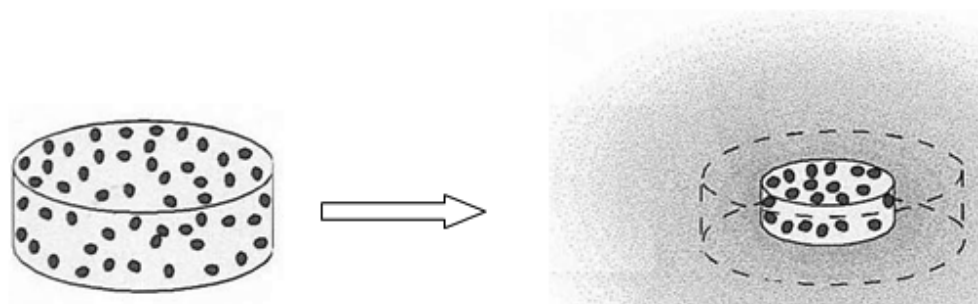

Figure 2. The drug entrapped in the PLGA matrix system is released by degradation of the polymer matrix ${ }^{(7)}$. 
The role of enzymes in biodegradation of PLGA is contraversial - with early literature concluding that spontaneous hydrolysis was the only mechanism. Further work indicates the conclusion that the PLGA biodegradation does not involve any enzymatic activity and is purely through hydrolysis. However, enzymes could potentially play a role in degradation for polymers in the rubbery state and enzymatic role in PLGA breakdown based upon the difference in the in vitro and in vivo degradation rates ${ }^{(50,66,81)}$.

The PLGA polymer biodegrades into lactic and glycolic acids ${ }^{(4,18,39,50,74,81)}$. Lactic acid, a normal byproduct of anaerobic metabolism in the human body, which is incorporated into the tricarboxylic acid (TCA) cycle and is metabolized and subsequently eliminated from the body as carbon dioxide and water ${ }^{(4)}$. Glycolic acid is either excreted unchanged in the kidney or it enters the tricarboxylic acid cycle and eventually eliminated as carbon dioxide and water. The degradation time of PLGA can be controlled from weeks to over a year by varying both the ratio of monomers and the processing condition ${ }^{(4,61)}$.

\section{FACTORS AFFECTING THE BIODEGRADATION OF PLGA}

Chemical composition, additives, crystallinity, porosity, molecular weight and molecular weight distribution, water permeability and solubility, mechanism of hydrolysis, morphology, device dimensions, glass transition temperature, sterilization, site of implantation are the factors affecting the biodegradation behaviour of PLGA based drug delivery devices ${ }^{(69)}$.

Shive and Anderson ${ }^{(69)}$ injected rats intramuscularly in the leg with norethistrone or lypressin microspheres prepared with radiolabelled PLGA microspheres of varying lactide:gycolide mole ratio in order to determine the biodegradation kinetics of microspheres prepared with lactide/gycolide exipients. The radiolabel was incorporated into the excipient by using ${ }^{14} \mathrm{C}$-DL-lactide monomer during its polymerization. Altering the chemical composition by increasing the gycolide mole ratio in the copolymer increases the rate of biodegradation (Fig. 3) (69).

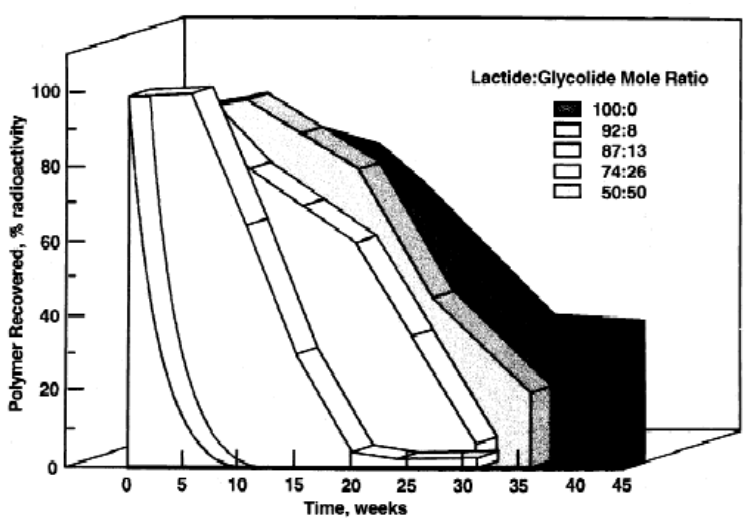

Figure 3. In vivo resorption rates of radiolabelled PLGA microspheres injected intramuscularly in rats. The fastest rate of degradation occurs with the 50:50 copolymer and as the glycolic acid content decreases, the rate of degradation decreases ${ }^{(68)}$.

Additives through their acidic or basic nature as well as loading level in the case of therapeutic agents may markedly affect the degradation rate of microspheres. Basic compounds can catalyze ester linkage scission and thus accelerate polymer degradation. On the other hand, appropriate amounts of basic compounds can neutralize carboxyl end groups and thus decrease the rate of degradation. This potential effect by the acidic/basic nature of the therapeutic agent incorporated must be considered in the design of PLGA based drug delivery devices ${ }^{(51)}$.

The crystallinity of the homopolymer or copolymer comprising the microcapsule may play a significant role in modulating the degradation rate. For semicrystalline polyesters, degradation first occurs in the amorphous domains and later in the crystalline regions. During the degradation process, the crystallinity gradually increases resulting in a high crystalline material which is much more resistant to hydrolysis than the starting polymer ${ }^{(8)}$.

Porosity of the microspheres may play a major role in enhancing the rate of biodegradation, especially when the pore dimensions are sufficiently large enough to permit cellular migration into the pores of the microsphere ${ }^{(69)}$.

Molecular weight and molecular weight distribution may play a role in the degradation behaviour. A large molecular weight distribution would indicate relatively large numbers of carboxylic end groups which can facilitate the autocatalytic degradation of the polymer chains. 
Large or wide molecular weight distributions thus would be expected to accelerate the rate of degradation whereas a narrow molecular weight distribution would have fewer carboxylic end groups available for catalysis ${ }^{(69)}$. Kamei and coworkers carried out a study in which two molecular weights of the copolymer were used: 10000 and 20000. It was demonstrated that the 10000 molecular weight polymer degraded approximately twice as fast as the 20000 molecular weight polymer ${ }^{(41)}$.

\section{PLGA BASED DRUG DELIVERY DEVICES}

PLGA has been used in various areas, such as the controlled release of encapsulated drugs, tissue engineering ${ }^{(79)}$, healing of bone defects ${ }^{(9)}$ and in vaccines ${ }^{(26)}$. The reasons for the widespread use of PLGA are its biodegradability, its biocompatibility, and the fact that drug products containing PLGA have been approved for parenteral use by regulatory authorities around the world $^{(28)}$. The disadvantage associated with PLGA is the production of acids upon degradation. Several techniques for the stabilization of acid-sensitive drugs have been investigated $^{(12,36,88)}$. Advantages of PLGAs are that they are commercially available with very different physico-chemical properties, and that the drug release profile can be tailored by selecting PLGAs with the appropriate properties, such as molecular weight $(\mathrm{Mw})$ and the lactide: gycolide ratio ${ }^{(89)}$. The duration of drug release can be varied from hours $^{(62)}$ to several months ${ }^{(48)}$. Furthermore, pulsed drug release is also possible ${ }^{(24)}$. Blending or co-polymerizing PLGA with other materials, or encapsulating PLGA microparticles in gels, further extends the possibility of controlling drug release ${ }^{(54)}$.

Numerous active pharmaceutical ingredients have been encapsulated in PLGA-based drug delivery systems (DDSs) with proven therapeutic effect in vivo, or have been released in concentrations considered sufficient for therapeutic effect, for example, siRNA ${ }^{(55)}$, proteins $^{(32)}$, anti-cancer drugs ${ }^{(53)}$, analgesic ${ }^{(84)}$, antibiotics ${ }^{(59)}$, and vaccines ${ }^{(19)}$. Among the different forms of PLGA-based DDSs, microspheres or microparticles are the most common. Other types include nanoparticles ${ }^{(68)}$, films $^{(45)}$, cylinders ${ }^{(22)}$, in situ forming implants or microparticles ${ }^{(23)}$, scaffolds $^{(82)}$, and foams ${ }^{(57)}$. PLGA implants may be surgically inserted at the desired location, giving the advantage of local drug delivery of, for example, antibiotics or anti-cancer drugs ${ }^{(80,83)}$.

The manufacturing techniques of PLGA particles are solvent evaporation and solvent extraction process, phase separation (coaservation) process and spray drying ${ }^{(38)}$.

\section{PLGA based drug delivery devices for tissue engineering}

Tissue engineering and regenerative medicine are emerging disciplines of biomedical research that promote the regeneration of tissues or the replacement of failing or multifunctioning organs. Three fundamental "tools", namely cells, scaffolds and bioactive molecules are used the repairing and restoring the damaged tissue function $^{(20,52)}$. The combination of adequate cells, scaffolds (that support and direct the growth of cells, and present appropriate physicochemical properties, mechanical strength and biodegradation profile) and bioactive molecules are used. These bioactive molecules essentially include proteins stimulating cell migration, proliferation or inducing cell differentiation, such as growth and neurotrophic factors ${ }^{(47)}$.

The selection of biomaterials plays a key role in the design and development of tissue engineering product development. Although the classical selection criterian for a safe, stable implant dictated choosing a passive, "inert" material, it is now understood that any such device will elicit a celluler response ${ }^{(60)}$. The incorporation of these bioactive proteins in PLGA nanoparticles could present several advantages. These systems in general can be used to provide targeted (cellular or tissue) delivery of drugs, which localized effect represents also an important benefit, because the administration of these proteins could present undesired side effects when they activate nontarget areas, improve bioavailability, sustain release of drugs or solubilize drugs for systemic delivery. This process can be adapted to protect therapeutic agents against enzymatic degradation $^{(20,31)}$. 


\section{PLGA based drug delivery devices for vascular engineering}

In tissue engineering, vascularization is one of the first requirements to achieve tissue regeneration. Complex organ constructs need a vascular supply system to guarantee survival and to render biological functions. Substantial efforts have been made over the past 10 years to create these vascular systems. There are three main approaches for engineering vascularized systems: (1) stimulating rapid vessel growth in a vascular implants with angiogenic factors, (2) seeding biodegradable bulk polymer scaffolds with endothelial cells and angiogenic factors, and (3) prevascularizing the acellular structures with stem cells before implantation ${ }^{(29,30,73,78)}$.

The delivery of angiogenic factors from implants has been widely investigated for establishing a vascular network within the developing tissue ${ }^{(21)}$. Vascular endothelial growth factor (VEGF) is an endothelial cell-specific mitogenic peptide and plays a key role in vasculogenesis and angiogenesis ${ }^{(25)}$. Incorporation of VEGF into PLGA scaffolds or into microspheres has shown the potential to protect and locally deliver VEGF at a more constant rate, leading to site-specific angiogenesis $^{(21)}$. Formiga et al. also prepared VEGF loaded microparticles and it was demonstrated that a single cytokine, VEGF, could exert not only an angiogenic but also an arteriogenic effect when delivered in vivo in a sustained manner, which translates into positive remodeling of the heart. Moreover, the use of microparticles allowed a dose-controlled release of the protein that can be easily and safely translated to patients ${ }^{(27)}$.

\section{PLGA based drug delivery devices for nerve regeneration}

Biodegradable synthetic nerve conduits have emerged as an alternative to autogenous grafts, and growth factors have been applied into the conduit lumen to increase nerve regeneration ${ }^{(70)}$. Schwann cells and the basal lamina, other than growth factors, also play a critical role in the early phase of nerve regeneration ${ }^{(14)}$. An ideal alternative conduit material including neurological substrates as well as growth factors could replace the autogenous nerve graft. The physiochemical and biological properties of PLGA can be tailored to match different application requirements, and some chemical modifications enable the materials effectively to entrap support cells (Schwann cells, laminins etc.) or bioactive molecules (nerve growth factor (NGF), brain-derived neurotrophic factor (BDNF), neurotrophin-3 (NT-3)) for controlled delivery during nerve regeneration ${ }^{(33)}$.

Bini et al. ${ }^{(13)}$ used PLGA in the ratio of 10:90 for the microbraiding of conduits which presented the advantages of flexibility, ease of suturing to the proximal and distal stumps, as well as a high degree of permeability for the exchange of nutrients. When implanted to bridge $1,2 \mathrm{~cm}$ gaps of the adult rat sciatic nerve, the conduit became filled with a fibrin matrix and by 1 month post operation, 9 of 10 rats revealed successful nerve regeneration. Furthermore, a thin fibrous tissue capsule which formed around the implant became vascularized suggesting good graft-host integration ${ }^{(13)}$.

VEGF-loaded poly(lactic-co-glycolic acid) (PLGA) microspheres were prepared ${ }^{(1,42,71,72)}$. Controlled release of VEGF was achieved during a 30-day period (Fig. 4) $)^{(43,72)}$ and with the help of an experimental model in rats, a nerve graft was prefabricated serving as a conduit instead of autologous nerve. The prefabricated nerve graft with the axons in an autogenous sheath was histologically similar to a real nerve. Nerve regeneration with the prefabricated nerve graft using VEGF loaded PLGA microspheres were similar to that achieved with an autogenous nerve graft for repairing nerve defects ${ }^{(42,43)}$.

\section{PLGA based drug delivery devices for carti- lage tissue engineering}

The demand for tissue engineered cartilage is immense because of the tissue's poor intrinsic healing potential; untreated degenerative and traumatic cartilage lesions often progress to degenerative arthritis ${ }^{(6,75)}$. Thus, applications in tissue engineering that improve cartilage repair have a high clinical impact. Biodegradable delivery devices that release bioactive insulin in a sustained manner are essential for the engineering of cartilage because insulin has a low half-life in vivo and is unstable 


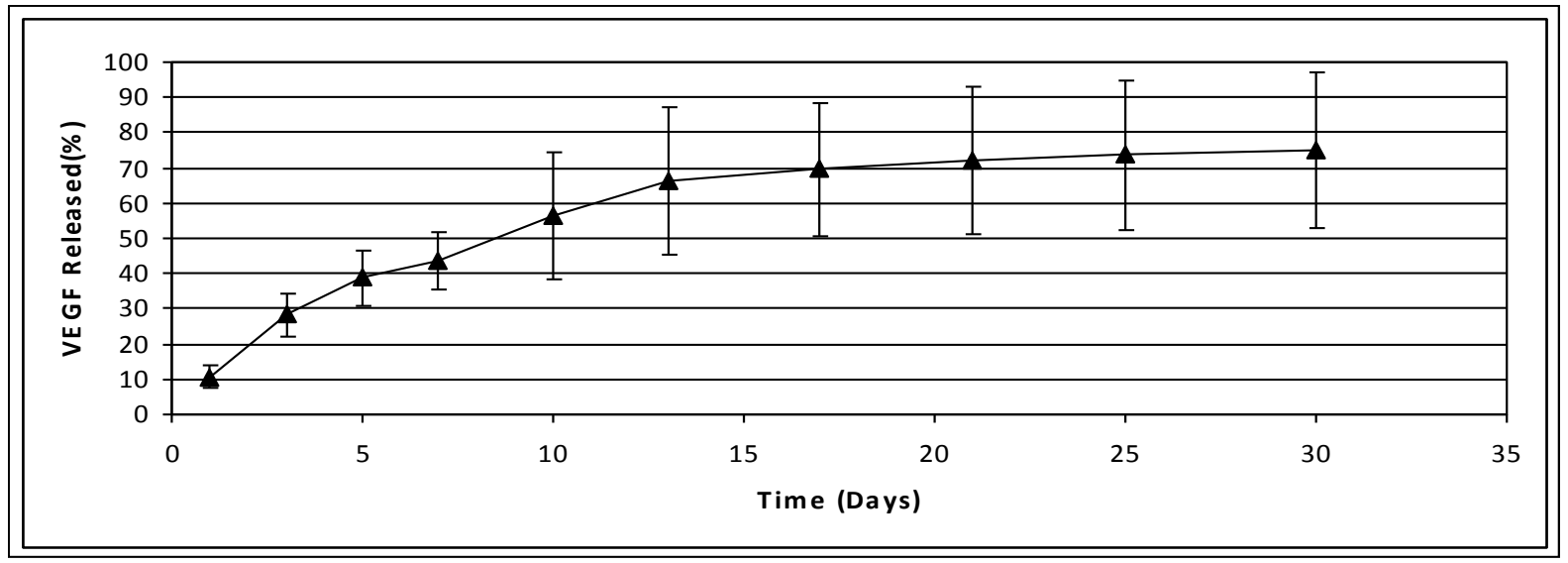

Figure 4. In vitro release profile of VEGF from PLGA microspheres during a 30 day period ${ }^{(43)}$.

in the presence of cartilage ${ }^{(15,16)}$. Insulin-loaded PLGA microspheres were prepared by Andreas et al. $^{(2)}$ and employed in a high density threedimensional (3D) in vitro cartilage engineering model. PLGA microspheres prepared by the $\mathrm{w} / \mathrm{o} / \mathrm{w}$ procedure showed sustained release of structurally intact and biologically active insulin that promoted the formation of cartilage-specific extracellular matrix (ECM) and thus represented a potent delivery device for application ${ }^{(2)}$. Apart from microspheres, PLGA scaffolds were also used for cartilage tissue engineering. Zhang et al. ${ }^{(86)}$ seeded porcine articular chondrocytes on the longitudinal oriented PLGA scaffolds (mimicking the microstructure of deep zone of articular cartilage) and cultured the samples in vitro for 12 weeks followed by another 12 weeks of subcutaneous implantation in nude mice. Cell migration on scaffolds, extracellular matrix production, as well as size, structure, and mechanical property of engineered cartilage were analyzed to evaluate the effects of the scaffold orientation on the structure and function of 3D cartilage formation. Oriented structure of scaffolds enhanced thickness, homogeneity, and mechanical property of in vitro engineered cartilage and thus provided a clue for improving in vitro cartilage regeneration. Most importantly, the in vitro engineered cartilage based on oriented scaffolds showed homogeneous and mature cartilage structure with abundant cartilage-specific ECM deposition after in vivo implantation, indicating a potential for in vivo cartilage repair ${ }^{(86)}$.

\section{PLGA based drug delivery devices for bone tissue engineering}

Bone tissue engineering is a highly interdisciplinary field that seeks to tackle the most challenging bone related clinical issues. The major components of bone tissue engineering that includes as well the use of 3-D systems are porous biodegradable scaffold, bone forming cells, and growth factors ${ }^{(35)}$.

Bone morphogenetic protein (BMP) is an effective growth factor that increases bone formation and recovery from diseases ${ }^{(76)}$. During the process of bone formation, signals from BMPs trigger the differentiation of stem cells, which are recruited to the site of injury, into bone forming cells ${ }^{(64)}$. Among them, BMP-2 and BMP-7, have been described as the most effective to induce complete bone morphogenesis and have been currently approved by $\operatorname{FDA}^{(10,77)}$. In order to provide this sequential time pattern of administration and also to increase the stability of the growth factors, BMP-2 was encapsulated in PLGA nanoparticles for an early release by Yilgor et al. ${ }^{(85)}$ When tested in an in vitro bioassay of the osteogenic differentiation into osteoblasts of rat bone marrow mesenchymal stem cells, a synergistic effect was observed with the sequential delivery of the BMPs in contrast with their single and simultaneous (using PLGA nanoparticles for both BMPs) delivery.

In another study, the release kinetics of recombinant human bone morphogenetic protein-2 (rhBMP-2) loaded PLGA/calcium phosphate cement (PLGA/Ca-P cement) composites 
were studied in vivo. RhBMP-2 was radiolabeled with 131I and entrapped within PLGA microparticles or adsorbed onto the microparticle surface. The in vitro and in vivo evaluation suggested that PLGA/Ca-P cement composites can be considered as sustained slow release vehicles and the release and retention of rhBMP2 can be modified according to the desired profile to a limited extent, the model was suitable as a scaffold for engineering bone tissue ${ }^{(65)}$.

Hydroxyapatite (HA) has been used extensively alone and in combination with polymers to form composite forms of a bone substitue ${ }^{(4)}$. Attawia et al. ${ }^{(5)}$ formed porous scaffolds containing PLGA and HA and seeded with osteoblasts harvested from rat calvaria. After only 24 hour, osteoblasts were seen to adhere to exterior surface of the scaffold and also to migrate into the pore structure. In a seperate study, the ability of the PLGA-HA scaffold to support osteoblast proliferation and differentiation as well as mineral formation over 21 days was examined ${ }^{(49)}$. The scaffolds used in these studies combined the degradability of the PLGA with the mechanical support of HA to form a tissue engineering replacement for bone defects.

Ishaug-Riley et al. ${ }^{(37)}$ cultured neonatal rat calvarial osteoblasts in $90 \%$ porous, $75: 25$ poly(DL-lactic-co-glycolic acid) (PLGA) foam scaffolds for up to 56 days to examine the effects of the cell seeding density, scaffold pore size, and foam thickness on the proliferation and function of the cells in this three-dimensional environment. PLGA foams are suitable substrates for osteoblast growth and differentiated function independent of cell source.

\section{CONCLUSION}

PLGA has been used by several researchers in tissue engineering, vascular engineering, nerve regeneration, cartilage tissue engineering and bone tissue engineering. Studies reviewed above show that PLGA is a succeesful biodegradable polymer as a controlled release system and a drug delivery device for tissue engineering and regenerative medicine. The selection of biomaterials plays a key role in the design and development of tissue engineering product development. The main reasons of the frequent use and the success of using PLGA polymer are its safety, biodegradability, biocompatibility. The incorporation of bioactive materials in PLGA drug delivery devices could present several advantages. These systems in general can be used to provide targeted (cellular or tissue) delivery of drugs, which localized effect represents also an important benefit. They improve bioavailability, sustain release of drugs or solubilize drugs for systemic delivery. This process can also be adapted to protect therapeutic agents against enzymatic degradation. As a future prospect, PLGA drug delivery systems are becoming more important for the prevention of tissue rejection, mimic in vivo conditions of the organs. Manufacturing processes should also be considered in order to be able to generate tissues on more of a mass scale. Also, automation of some of the cell culture techniques as well as making the generation and transportation of tissues compatible with surgical techniques should expand the opportunities for future tissue engineers.

\section{REFERENCES}

1. Alarçin E, Sipahigil O, Türkoğlu M et al. Cell proliferation and cytotoxicity evaluation of vascular endothelial growth factor loaded poly(lactic-coglycolic acid) microspheres, 15th International Pharmaceutical Technology Symposium, Proceeding Abstracts, p:121-2, Antalya (2010).

2. Andreas $\mathrm{K}$, Zehbe $\mathrm{R}$, Kazubek $\mathrm{M}$ et al. Biodegradable insulin-loaded PLGA microspheres fabricated by three different emulsification techniques: Investigation for cartilage tissue engineering, Acta Biomater 2011;7(4):1485-95.

http://dx.doi.org/10.1016/j.actbio.2010.12.014 PMid:21168535

3. Armentano I, Dttori M, Fortunati $E$ et al. Biodegradable polymer matrix nanocomposites for tissue engineering: A review, Polym Degrad Stab 2010;95:2126-46.

http:/ / dx.doi.org/10.1016/j.polymdegradstab.2010.06.007

4. Atala A, Robert PL (eds). Methods of Tissue Engineering, Academic Press, USA (2002).

5. Attawia MA, Herbert KM, Laurencin CT. 
Osteoblast like cell adherence and migration through 3-dimensional porous polymer matrices, Biochem Biophys Res Commun 1995;213(2):639-44.

http://dx.doi.org/10.1006/bbrc.1995.2179 PMid:7646521

6. Bala I, Hariharan S, Kumar MN. PLGA nanoparticles in drug delivery: the state of the art, Crit Rev Ther Drug Carrier Syst 2004;21(5):387-422.

http:/ / dx.doi.org/10.1615/CritRevTherDrug CarrierSyst.v21.i5.20

PMid:15719481

7. Baldwin SP, Saltzman WM. Materials for protein delivery in tissue engineering, Adv Drug Deliv Rev 1998;33(1-2):71-86.

http://dx.doi.org/10.1016/S0169-409X(98)00021-0

8. Bergsma EJ, Rozema FR, Bos RR, de Bruijn WC. Foreign body reactions to resorbable poly(L-lactide) bone plates and screws used for fixation of unstable zygomatic fractures, J Oral Maxillofac Surg 1993; 51(6):666-70.

http://dx.doi.org/10.1016/S0278-2391(10)80267-8

9. Bertoldi C, Zaffe D, Consolo U. Polylactide/ polyglycolide copolymer in bone defect healing in humans, Biomaterials 2008;29(12):1817-23.

http://dx.doi.org/10.1016/j.biomaterials.2007.12.034

PMid:18234328

10. Bessa PC, Casal M, Reis RL. Bone morphogenetic proteins in tissue engineering: the road from the laboratory to the clinic, part I (basic concepts), J Tissue Eng Regen Med 2008;2(1):1-13. http:/ /dx.doi.org/10.1002/term.63 PMid:18293427

11. Bilati U, Allemann E, Doelker E. Poly (D,L-lactideco-glycolide) protein loaded nanoparticles prepared by the double emulsion method-processing and formulation issues for enhanced entrapment efficiency, J Microencapsul 2005;22(2):205-14.

http://dx.doi.org/10.1080/02652040400026442 PMid:16019905

12. Bilati U, Allemann E, Doelker E. Strategic approaches for overcoming peptide and protein instability with biodegradable nano-and microparticles, Eur J Pharm Biopharm 2005;59(3):375-88.

http://dx.doi.org/10.1016/j.ejpb.2004.10.006

PMid:15760718

13. Bini TB, Gao S, Xu X, Wang S, Ramakrishna S, Leong KW. Peripheral nerve regeneration by microbraided poly(L-lactide-co-glycolide) biodegradable polymer fibers, J Biomed Mater Res A 2004;68(2):286-95.

http://dx.doi.org/10.1002/jbm.a.20050

PMid:14704970
14. Bryan DJ, Wang KK, Chakalis-Haley DP. Effect of Schwann cells in the enhancement of peripheral nerve regeneration, J Reconstr Microsurg 1996; 12(7):439-46.

http://dx.doi.org/10.1055/s-2007-1006616 PMid:8905543

15. Burt RL, Davidson IW. Insulin half-life and utilization in normal pregnancy, Obstet Gynecol 1974;43(2):161-70. PMid:4855689

16. Cai L, Okumu FW, Cleland JL et al. A slow release formulation of insulin as a treatment for osteoarthritis, Osteoarthritis Cartilage 2002;10(9):692-706. http://dx.doi.org/10.1053/joca.2002.0813 PMid:12202122

17. Carrasqullio KG, Stanley AM, Aponto-Carro JC et al. Non-aqueous encapsulation of exipient stabilized spray freeze dried BSA into poly (D,Llactide-co-glycolide) microspheres results in release of native protein, $J$ Control Release 2001;76(3):199-208. http:/ /dx.doi.org/10.1016/S0168-3659(01)00430-8

18. Cohen S, Alonso MJ, Langer R. Novel approaches to controlled release antigen delivery, Int J Technol Assessment Health Care 1994;10(1):121-30. http://dx.doi.org/10.1017/S0266462300014045

19. Cui C, Stevens VC, Schewendeman SP. Injectable polymer microspheres enhance immunogenicity of a contraceptive peptide vaccine, Vaccine 2007;25(3):500-9.

http://dx.doi.org/10.1016/j.vaccine.2006.07.055 PMid:16996662

20. Danhier F, Ansorena E, Silva JM, Coco R, Le Breton A, Préat V. PLGA-based nanoparticles: An overview of biomedical applications, J Control Release 2012.

http://dx.doi.org/10.1016/j.jconrel.2012.01.043 PMid:22353619

21. des Rieux A, Ucakar B, Mupendwa BP et al. 3D systems delivering VEGF to promote angiogenesis for tissue engineering, J Control Release 2011; 150(3):272-8.

http://dx.doi.org/10.1016/j.jconrel.2010.11.028 PMid:21130820

22. Desai, KGH, Olsen KF, Mallery SR, Stoner GD, Schwendeman SP. Formulation and in vitro and in vivo evaluation of black raspberry extract loaded PLGA/PLA injectable millicylindrical implants for sustained delivery of chemopreventive anthocyanins, Pharm Res 2010;27(4):628-43. http:/ /dx.doi.org/10.1007/s11095-009-0038-5 PMid:20148292 PMCid:2880396

23. Dong WY, Körber M, López Esguerra V, Bodmeier 
R. Stability of poly(D,L-lactide-co-glycolide) and leuprolide acetate in in situ forming drug delivery systems, J Control Release 2006;115(2):158-67.

http://dx.doi.org/10.1016/j.jconrel.2006.07.013 PMid:16963145

24. Dorta MJ, Santovena A, Llabrés M, Farina JB. Potential application of PLGA film implants in modulating in vitro drugs release, Int $J$ Pharm 2002;248(1-2):149-56. http://dx.doi.org/10.1016/S0378-5173(02)00431-3

25. Dvorak HF, Brown LF, Detmar M, Dvorak AM. Vascular permeability factor/vascular endothelial growth factor, microvascular hyperpermeability, and angiogenesis, Am J Pathol 1995;146(5):1029-39. PMid:7538264 PMCid:1869291

26. Feng L, Qi XR, Zhou XJ et al. Pharmaceutical and immunological evaluation of a single dose hepatitis vaccine using PLGA microspheres, J Control Release 2006;112(1):35-42.

http://dx.doi.org/10.1016/j.jconrel.2006.01.012 PMid:16516999

27. Formiga FR, Pelacho B, Garbayo E et al. Sustained release of VEGF through PLGA microparticles improves vasculogenesis and tissue remodeling in an acute myocardial ischemia-reperfusion model, J Control Release 2010;147(1):30-7. http://dx.doi.org/10.1016/j.jconrel.2010.07.097 PMid:20643169

28. Fredenberg S, Wahlgren M, Reslow M, Axelsson A. The mechanism of drug release in poly(lacticco-glycolic) acid- based drug delivery systems:A review, Int J Pharm 2011;415(1-2):34-52. http://dx.doi.org/10.1016/j.ijpharm.2011.05.049 PMid:21640806

29. Freed LE, Vunjak-Novakovic G, Biron RJ et al. Biodegradable polymer scaffolds for tissue engineering, Nature Biotech 1994;12(7):689-93.

http://dx.doi.org/10.1038/nbt0794-689 PMid:7764913

30. Frerich B, Lindemann N, Kurtz-Hoffmann J, Oertel $K$. In vitro model of a vascular stroma for the engineering of vascularized tissues, Int $J$ Oral Maxillofac Surg 2001;30(5):414-20.

http:/ /dx.doi.org/10.1054/ijom.2001.0130 PMid:11720044

31. Ge H, Hu Y, Jiang $\mathrm{X}$ et al. Preparation, characterization, and drug release behaviors of drug nimodipine-loaded poly (epsilon-caprolactone)poly(ethylene oxide)-poly(epsilon-caprolactone) amphiphilic triblock copolymer micelles, J Pharm Sci 2002;91(6):1463-73.

http://dx.doi.org/10.1002/jps.10143

PMid:12115846
32. Gu H, Song C, Long D, Mei L, Sun H. Controlled release of recombinant human nerve growth factor (rhNGF) from poly[(lactic acid)-co(glycolic acid)] microspheres for the treatment of neurodegenerative disorders, Polym Int 2007;56(10):127280.

http://dx.doi.org/10.1002/pi.2272

33. Gu X, Ding F, Yang Y, Liu J. Construction of tissue engineered nerve grafts and their application in peripheral nerve regeneration, Prog Neurobiol 2011;93(2):204-30.

http://dx.doi.org/10.1016/j.pneurobio.2010.11.002 PMid:21130136

34. Hanafusa S, Matsusue $\mathrm{Y}$, Yasunaga $\mathrm{T}$ et al. Biodegradable plate fixation of rabbit femoral shaft osteotomies. A comparative study, Clin Orthop Relat Res 1995;315:262-71.

PMid:7634680

35. Holzwarth JM, Ma PX. Biomimetic nanofibrous scaffolds for bone tissue engineering, Biomaterials 2011;32(36):9622-9.

http://dx.doi.org/10.1016/j.biomaterials.2011.09.009 PMid:21944829

36. Houchin ML, Topp EM. Chemical degradation of peptides and proteins in PLGA: a review of reactions and mechanisms, J Pharm Sci 2008;97(7):2395404.

http://dx.doi.org/10.1002/jps.21176

PMid:17828756

37. Ishaug-Riley SL, Crane-Kruger GM, Yaszemski MJ, Mikos AG. Three-dimensional culture of rat calvarial osteoblasts in porous biodegradable polymers, Biomaterials 1998;19(15):1405-12. http:/ /dx.doi.org/10.1016/S0142-9612(98)00021-0

38. Jain RA. The manufacturing techniques of various drug loaded biodegradable poly (D,L-lactide-coglycolide) (PLGA) devices, Biomaterials 2000;21(23): 2475-90. http://dx.doi.org/10.1016/S0142-9612(00)00115-0

39. Jalil R, Nixon JR. Biodegradable poly(lactic acid) and poly(lactide-co-gycolide) microcapsules: problems associated with preparative techniques and release properties, $J$ Microencapsulation 1990;7(3):297-325.

http://dx.doi.org/10.3109/02652049009021842 PMid:2200861

40. Jamshidi K, Hyon SH, Ikada Y. Thermal characterization of polylactides, Polymer 1988;29(12):2229-34. http://dx.doi.org/10.1016/0032-3861(88)90116-4

41. Kamei S, Inoue Y, Okada H, Yamada M, Ogawa Y, Toguchi H. New method for analysis of biodegradable polyesters by high performance liquid chromarography after alkali hydrolysis, 
Biomaterials 1992;33(13):953-8.

http:/ /dx.doi.org/10.1016/0142-9612(92)90120-D

42. Karagöz H, Ülkür E, Sipahigil O et al. Nerve graft prefabrication using vascular endothelial growth factor-loaded poly(lactic-co-glycolic acid) microspheres, Turkish Society of Plastic Reconstructive and Aesthetic Surgery, 33rd The National Assembly, İzmir (2011).

43. Karagöz H, Ülkür E, Sipahigil O et al. Vascular endothelial growth factor-loaded poly(lactic-coglycolic acid) microspheres-induced lateral axonal sprouting into the vein graft bridging two healthy nerves: nerve graft prefabrication using controlled release system, Microsurgery, article in press.

44. Kim DH, Martin DC. Sustained release of dexamethasone from hydrophilic matrices using PLGA nanoparticles for neural drug delivery, Biomaterials 2006;27(15):3031-7.

http:/ /dx.doi.org/10.1016/j.biomaterials.2005.12.021 PMid:16443270

45. Klose D, Siepmann F, Elkharraz K, Siepmann J. PLGA based drug delivery systems: importance of the type of drug and device geometry, Int J Pharm 2008;354(1-2):95-103.

http:/ /dx.doi.org/10.1016/j.ijpharm.2007.10.030 PMid:18055140

46. Kumari A, Yadav SK, Yadav SC. Biodegradable polymeric nanoparticles based drug delivery systems, Colloids Surf B Biointerfaces 2010;75(1):1-18. http:/ /dx.doi.org/10.1016/j.colsurfb.2009.09.001 PMid:19782542

47. Ladewig K. Drug delivery in soft tissue engineering, Expert Opin Drug Deliv 2011;8(9):1175-88. http:/ /dx.doi.org/10.1517/17425247.2011.588698 PMid:21679089

48. Lagarce F, Renaud P, Faisant N et al. Baclofen loaded microspheres: preparation and efficacy testing in a new rabbit model, Eur J Pharm Biopharm 2005;59(3):449-59.

http:/ /dx.doi.org/10.1016/j.ejpb.2004.08.013 PMid:15760725

49. Laurencin CT, Attawia MA, Elgendy HE, Herbert KM. Tissue engineered bone regeneration using degradable polymer: The formation of mineralized matrices, Bone 1996;19(Suppl 1):S93-9. http:/ /dx.doi.org/10.1016/S8756-3282(96)00132-9

50. Lewis DH. Controlled release of bioactive agents from lactide/glycolide polymers, "Chasin M, Langer R (eds): Biodegradable Polymers as Drug Delivery Systems" p.1-41, Marcel Dekker, New York (1990).

51. Li S, Vert M. Biodegradation of aliphatic polyesters, "Scott G, Gilead D (eds). Degradable
Polymers" Chapter 4, p. 43-87, Chapman and Hall, London (1995).

52. Mikos AG, Herring SW, Ochareon $\mathrm{P}$ et al. Engineering complex tissues, Tissue Eng 2006; 12(12):3307-39.

http:/ /dx.doi.org/10.1089/ten.2006.12.3307

PMid:17518671 PMCid:2821210

53. Mo Y, Lim LY. Paclitaxel loaded PLGA nanoparticles: potentiation of anti cancer activity by surface conjugation with wheat germ agglutinin, J Control Release 2005;108(2-3):244-62.

http:/ /dx.doi.org/10.1016/j.jconrel.2005.08.013 PMid:16213056

54. Mundargi RC, Babu VR, Rangaswamy V, Patel P, Aminabhavi TM. Nano/micro technologies for delivering macromolecular therapeutics using poly (D,L-lactide-co-glycolide) and its derivatives, J Contr Release 2008;125(3):193-209.

http:/ /dx.doi.org/10.1016/j.jconrel.2007.09.013 PMid:18083265

55. Murata N, Takashima Y, Toyoshima K, Yamamoto M, Okada H. Anti tumor effects of anti VEGF siRNA encapsulated with PLGA microspheres in mice, J Conrol Release 2008;126(3):246-54.

http:/ /dx.doi.org/10.1016/j.jconrel.2007.11.017 PMid:18215787

56. Nieddu E, Mazzucco L, Gentile P et al. Preparation and biodegradation of clay composites of PLA, Reactive Functional Polymers 2009;69(6):371-9. http:/ / dx.doi.org/10.1016/j.reactfunctpolym.2009.03.002

57. Ong BY, Ranganath SH, Lee LY et al. Paclitaxel delivery from PLGA foams for controlled release in post surgical chemotherapy against glioblastoma multiforme, Biomaterials 2009;30(18):3189-96. http:/ /dx.doi.org/10.1016/j.biomaterials.2009.02.030 PMid:19285718

58. Panyam J, Labhasetwar V. Biodegradable nanoparticles for drug and gene delivery to cells and tissue, Adv Drug Deliv Rev 2003;55(3):329-47. http:/ /dx.doi.org/10.1016/S0169-409X(02)00228-4

59. Patel P, Mundargi RC, Babu VR, Jain D, Rangaswamy V, Aminabhavi TM. Microencapsulation of doxycycline into poly(lactide-co-glycolide) by spray drying technique: effect of polymer molecular weight on process parameters, $J$ Appl Polym Sci 2008;108(6):4038-46. http:/ /dx.doi.org/10.1002/app.28040

60. Peppas NA, Langer R. New challenges in biomaterials, Science 1994;263(5154):1715-20. http:/ /dx.doi.org/10.1126/science.8134835 PMid:8134835

61. Ralner BD, Hoffman S, Schoen FJ et al. Biomaterials 
Science "An Introduction to Materials in Medicine", 2nd ed, Elsevier Academic Press, China (2004).

62. Ratajczak-Emselme M, Estebe JP, Dollo G et al. Epidural, intrathecal and plasma pharmacokinetics study of epidural ropivacaine in PLGA microspheres in sheep model, Eur J Pharm Biopharm 2009;72(1):54-61.

http:/ /dx.doi.org/10.1016/j.ejpb.2008.11.003 PMid:19061956

63. Ravi Kumar MN, Bakowsky U, Lehr CM. Preparation and characterization of cationic PLGA nanospheres as DNA carriers, Biomaterials 2004;25(10):1771-7.

http:/ /dx.doi.org/10.1016/j.biomaterials.2003.08.069 PMid:14738840

64. Reddi AH. Cell biology and biochemistry of endochondral bone development, Coll Relat Res 1981;1(2):209-26.

http: / /dx.doi.org/10.1016/S0174-173X(81)80021-0

65. Ruhé PQ, Boerman OC, Russel FG, Spauwen PH, Mikos AG, Jansen JA. Controlled release of rhBMP-2 loaded poly(dl-lactic-co-glycolic acid)/ calcium phosphate cement composites in vivo, $J$ Control Release 2005;106(1-2):162-71.

http:/ /dx.doi.org/10.1016/j.jconrel.2005.04.018 PMid:15972241

66. Sanders LM, Wayne Hendren R. Protein Delivery, Plenum Press, New York (1997).

67. Schulze-Tanzil G. Activation and dedifferentiation of chondrocytes: Implications in cartilage injury and repair, Ann Anat 2009;191(4):325-38. http:/ /dx.doi.org/10.1016/j.aanat.2009.05.003 PMid:19541465

68. Sharma G, Italia JL, Sonaje K, Tikoo K, Ravi Kumar MN. Biodegradable in situ gelling system for subcutaneous administration of ellagic acid and ellagic acid loaded nanoparticles: evaluation of their antioxidant potential against cyclosporine induced nephrotoxicity in rats, J Control Release 2007;118(1):27-37.

http://dx.doi.org/10.1016/j.jconrel.2006.11.026 PMid:17258836

69. Shive MS, Anderson JM. Biodegradation and biocompatibility of PLA and PLGA microspheres, Adv Drug Deliv Rev 1997;28(1):5-24. http:/ /dx.doi.org/10.1016/S0169-409X(97)00048-3

70. Siemionow M, Bozkurt M, Zor F. Regeneration and repair of peripheral nerves with different biomaterials: Review, Microsurg 2010;30(7):574-88.

http:/ /dx.doi.org/10.1002/micr.20799

PMid:20878689

71. Sipahigil O, Alarçin E, Türkoğlu $M$ et al.
Preparation and characterization of vascular endothelial growth factor loaded poly(lactic-coglycolic acid) microspheres, 3rd International Meeting on Pharmacy and Pharmaceutical Sciences, Proceeding Abstracts, p:73, İstanbul (2010).

72. Sipahigil O, Alarçin E, Türkoğlu $M$ et al. Characterization, cell proliferation and cytotoxicity evaluation of vascular endothelial growth factor loaded poly(lactic-co-glycolic acid) microspheres, Nobel Med 2012; 8 (1): 77-82.

73. Tabata Y, Miyao M, Ozeki M, Ikada Y. Controlled release of vascular endothelial growth factor by use of collagen hydrogels, Biomater Sci Polym Ed 2000;11(9):915-30.

74. Tice TR, Tabibi ES. Parenteral drug delivery: injectables, "Kydonieus A (ed): Treatise on Controlled Drug Delivery: Fundamentals, Optimization, Applications" p.315-39, Marcel Dekker, New York (1991).

75. Tuli R, Li WJ, Tuan RS. Current state of cartilage tissue engineering, Arthritis Res Ther 2003;5(5): 235-8. http:/ / dx.doi.org/10.1186/ar991

76. Umeki N, Sato T, Harada M et al. Preparation and evaluation of biodegradable microspheres containing a new potent osteogenic compound and new synthetic polymers for sustained release, Int J Pharm 2010;392(1-2):42-50.

http:/ / dx.doi.org/10.1016/j.ijpharm.2010.03.020 PMid:20227474

77. Vo TN, Kasper FK, Mikos AG. Strategies for controlled delivery of growth factors and cells for bone regeneration, Adv Drug Deliv Rev 2012, http:/ /dx.doi.org/10.1016/j.addr.2012.01.016 PMid:22342771

78. Wang X, Mäkitie AA, Paloheimo KS et al. Characterization of a PLGA sandwiched cell/ fibrin tubular construct and induction of the adipose derived stem cells into smooth muscle cells, Materials Science Engineering C 2011;31(4):801-8. http:/ / dx.doi.org/10.1016/j.msec.2010.10.007

79. Wang X, Sui S, Yan Y, Zhang R. Design and fabrication of PLGA sandwiched cell/fibrin constructs for complex organ regeneration, I Bioactive Compatible Polym 2010;25(3):229-40. http:/ /dx.doi.org/10.1177/0883911510365661

80. Weinberg BD, Blanco E, Gao J. Polymer implants for intratumoral drug delivery and cancer therapy, J Pharm Sci 2008;97(5):1681-702. http:/ /dx.doi.org/10.1002/jps.21038 PMid:17847077

81. Wu XS. Synthesis and properties of biodegradable 
lactic/glycolic acid polymers. "Wise et al. (eds): Encyclopedic Handbook of Biomaterials and Bioengineering" p. 1151-200, Marcel and Dekker, New York, (1995).

82. Xiong Y, Zeng YS, Zeng CG et al. Synaptic transmission of neural stem cells seeded in 3-dimensional PLGA scaffolds, Biomaterials 2009;30(22): 3711-22.

http:/ /dx.doi.org/10.1016/j.biomaterials.2009.03.046 PMid:19375792

83. Xu Q, Czernuszka JT. Controlled release of amoxicillin hydroxyapatite coated poly(lactic-co-glycolic acid) microspheres, J Control Release 2008;1 27(2):146-53.

http:/ /dx.doi.org/10.1016/j.jconrel.2008.01.017 PMid:18325617

84. Yen SY, Sung KC, Wang JJ, Yoa-Pu Hu O. Controlled release of nalbuphine propionate from biodegradable microspheres: in vitro and in vivo studies, Int J Pharm 2001;220(1-2):91-9. http:/ /dx.doi.org/10.1016/S0378-5173(01)00649-4

85. Yilgor P, Hasirci N, Hasirci V. Sequential BMP-2/ BMP-7 delivery from polyester nanocapsules, $J$ Biomed Mater Res A 2010;93(2):528-36.
PMid:19585564

86. Zhang Y, Yang F, Liu K et al. The impact of PLGA scaffold orientation on in vitro cartilage regeneration, Biomaterials 2012;33(10):2926-35.

http:/ /dx.doi.org/10.1016/j.biomaterials.2012.01.006 PMid:22257722

87. Zhou H, Lawrence JG, Bhaduri SB. Fabrication aspects of PLA-CaP/PLGA-CaP composites for orthopedic applications: A review, Acta Biomater 2012.

http:/ /dx.doi.org/10.1016/j.actbio.2012.01.031 PMid:22342596

88. Zhu G, Schewendeman SP. Stabilization of proteins encapsulated in cylindirical poly(lactide-coglycolide) implants: mechanisms of stabilization by basic additives, Pharm Res 2000;17(3):351-7. http:/ /dx.doi.org/10.1023/A:1007513425337 PMid:10801225

89. Zolnik BS, Burgess DJ. Evaluation of in vivo-in vitro release of dexamethasone from PLGA microspheres, J Control Release 2008;127(2):137-45. http:/ /dx.doi.org/10.1016/j.jconrel.2008.01.004 PMid:18282629 